\title{
Self-administration of Mercury by Subcutaneous Injection
}

\author{
D. M. HILL,* M.A., B.M., M.R.C.P.
}

Brit. med. F., 1967, 1, 342-343

Although an ancient metal, the toxicology of mercury remains only partially understood (Hunter, 1962 ; Bidstrup, 1964). In the following case report details of dosage, effect, and subsequent elimination of metallic mercury are given.

\section{Case Report}

An unmarried woman of 21 developed diabetes mellitus in 1957 when aged 12. Her subsequent management was often complicated by diabetic ketoacidosis and coma, eventually traced to failure to administer her insulin correctly. At a number of centres in the London area she received psychiatric treatment, with a diagnosis of inadequate immature personality and psychopathic features.

In 1962, at the age of 18 , she was referred to the diabetic department of King's College Hospital after further diabetic difficulties and recurrent infections of the urinary tract. Considerable time was given by the medical and psychiatric staff to her case; in 1964 she spent 63 days as an inpatient during 17 separate hospital admissions.

On 8 March 1965, while working as a part-time dental receptionist and receiving her insulin by twice-daily visits from a district nurse, she presented at the casualty department of King's College Hospital with a week's history of an abscess in each thigh at the sites of insulin injections.

Examination.- Her general condition was satisfactory, temperature $100^{\circ} \mathrm{F}$. $\left(37.8^{\circ} \mathrm{C}\right.$.), and she was not drowsy, dehydrated, or ketotic. On the anterior aspect of the right mid-thigh was a large ( 6 by 5 in. ; 15 by $12.5 \mathrm{~cm}$.) tender fluctuant abscess with surrounding erythema. A smaller abscess ( 2 by 1 in.; 5 by $2.5 \mathrm{~cm}$.) was present at a similar site on the left thigh. There was no inguinal lymphadenopathy, and the remaining systems were normal without evidence of diabetic complications. Her weight was $10 \mathrm{st} .(63.5 \mathrm{~kg}$.) ; height $5 \mathrm{ft} .4$ in. $(163 \mathrm{~cm}$.).

The diabetes was managed with a 120-g. carbohydrate diet and a twice-daily soluble and isophane insulin regimen (Oakley et al., 1966). The daily insulin requirement was initially 80 units, falling shortly to 60 units, without difficulty of control while under ward supervision.

\section{Investigations}

After a short period of bed rest and antibiotics, during which the surrounding cellulitis subsided, the right abscess was drained by incision on $13 \mathrm{March}$, approximately $100 \mathrm{ml}$. of sterile pus being removed. Next day the nursing staff were surprised to find droplets of metallic mercury on the soiled dressings, and pressure around the wound produced further small quantities of mercury. Immediate $x$-ray examination showed subcutaneous deposits of mercury below each abscess (Fig. 1), estimated at between 0.5 and $1 \mathrm{ml}$. on each side. The patient denied any knowledge of its administration. Partially successful attempts were made to incise both abscesses and remove mercury by dissection and suction, but a residual quantity tracked away from the operator and was shown radiologically on each occasion to have dispersed into finer particles.

No symptoms or signs of acute mercury poisoning developed at any time, but blood and urine mercury levels measured at the Laboratory of the Government Chemist (Analytical Methods Committee, 1965) were within the range encountered in chronic mercury poisoning, and it was decided after consultation with Dr. R. Goulding, of the National Poisons Information Service, to carry out block dissections of the mercury deposits in the thighs under radiological control. These took place on 18 and 28 May (Mr.

- Lecturer in Medicine, King's College Hospital Medical School, London S.E.5
A. J. Heriot and Mr. J. M. Powley), each being covered with a week's course of dimercaprol (6 mg./kg./day). Blocks of skin and subcutaneous fat weighing 111 and 188 g. (Figs. 2 and 3 ) were excised from the right and left sides respectively, and were found on analysis (Analytical Methods Committee, 1965) to contain 1.7 and $1.8 \mathrm{~g}$. of mercury. The left scar healed normally, the right very slowly by secondary intent, though radiology showed no residual mercury deposits.

Serial blood and urine mercury levels were followed (Fig. 4). Neither proteinuria nor any change in urine microscopy developed, but creatinine clearance was reduced between May and October (47 to $65 \mathrm{ml} . / \mathrm{min}$.). Blood urea and intravenous pyelograms were normal. A renal biopsy specimen was not obtained. There was no radiological evidence of distant mercurial emboli. No other biochemical abnormalities were noted, and on 5 August the patient was discharged from hospital. Follow-up over a further year has shown no subsequent deterioration, and neither symptoms nor signs of chronic mercurialism have been observed.

Histology of Excised Subcutaneous Tissue.-Sections showed the fatty connective tissue infiltrated by granulation tissue with fibrosis and chronic inflammatory cells, including occasional giant cells around dense metallic globules (Fig. 5).

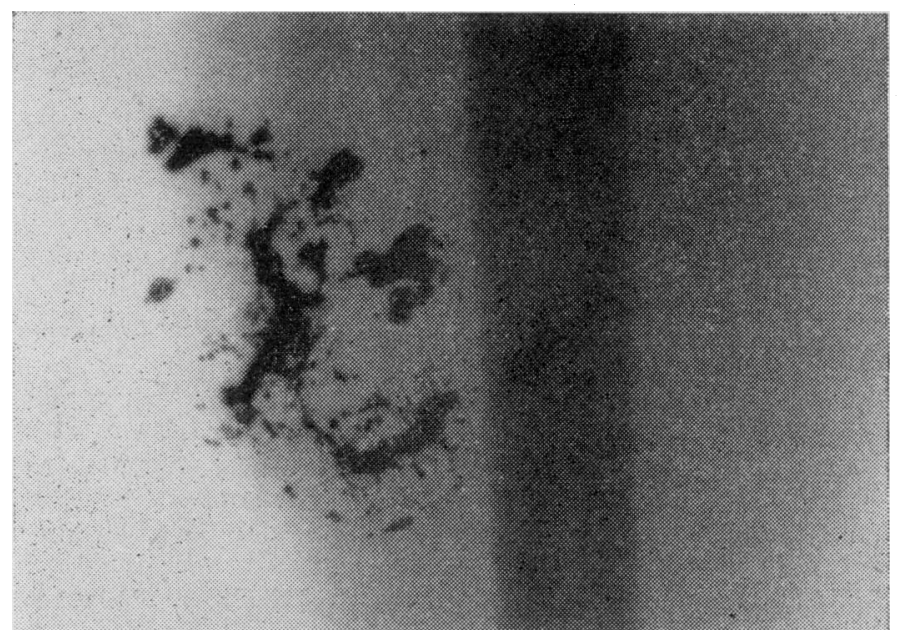

FIG. 1.-X-ray film of right mid-thigh showing mercury deposits.

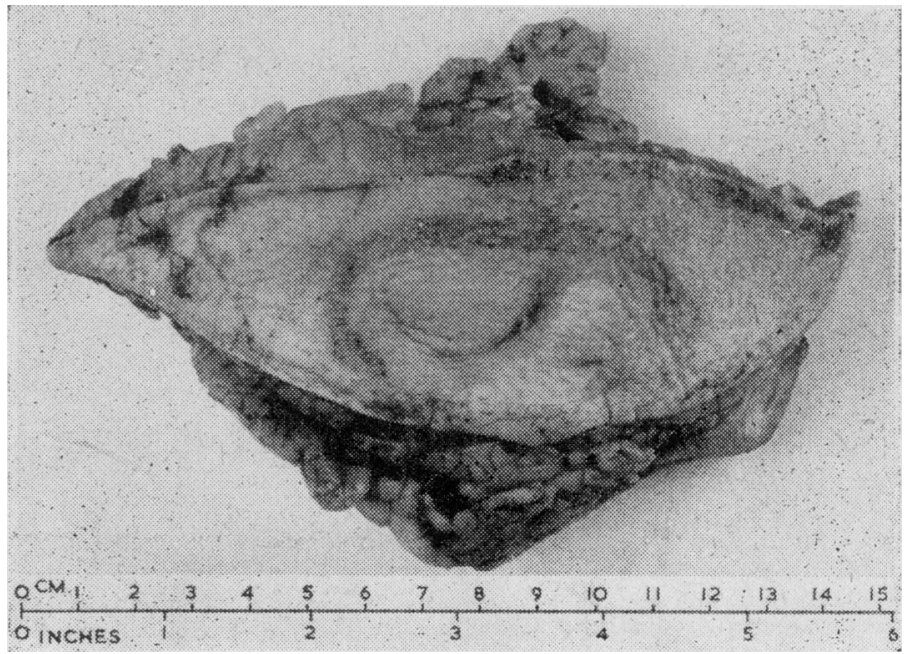

Fic. 2.-Excised block of right thigh skin and subcutaneous tissue. 


\section{Discussion}

Though mercury was used as a systemic treatment, principally for tuberculosis and syphilis, for some 400 years up to the 1920 s, authorities differ in their accounts of the frequency of ill effects (Richter, 1910 ; Goodman and Gillman, 1955;

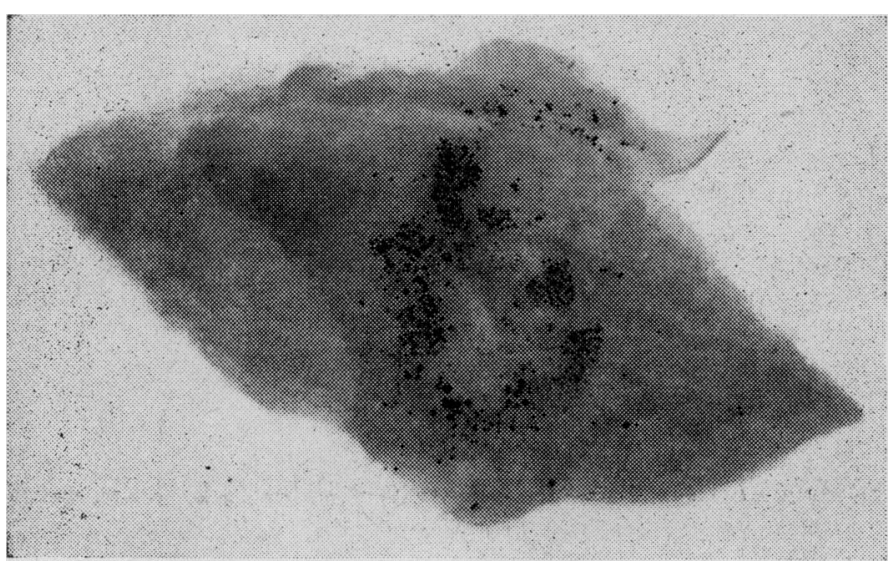

Fig. 3. $-X$-ray film of block of right thigh tissue after excision.
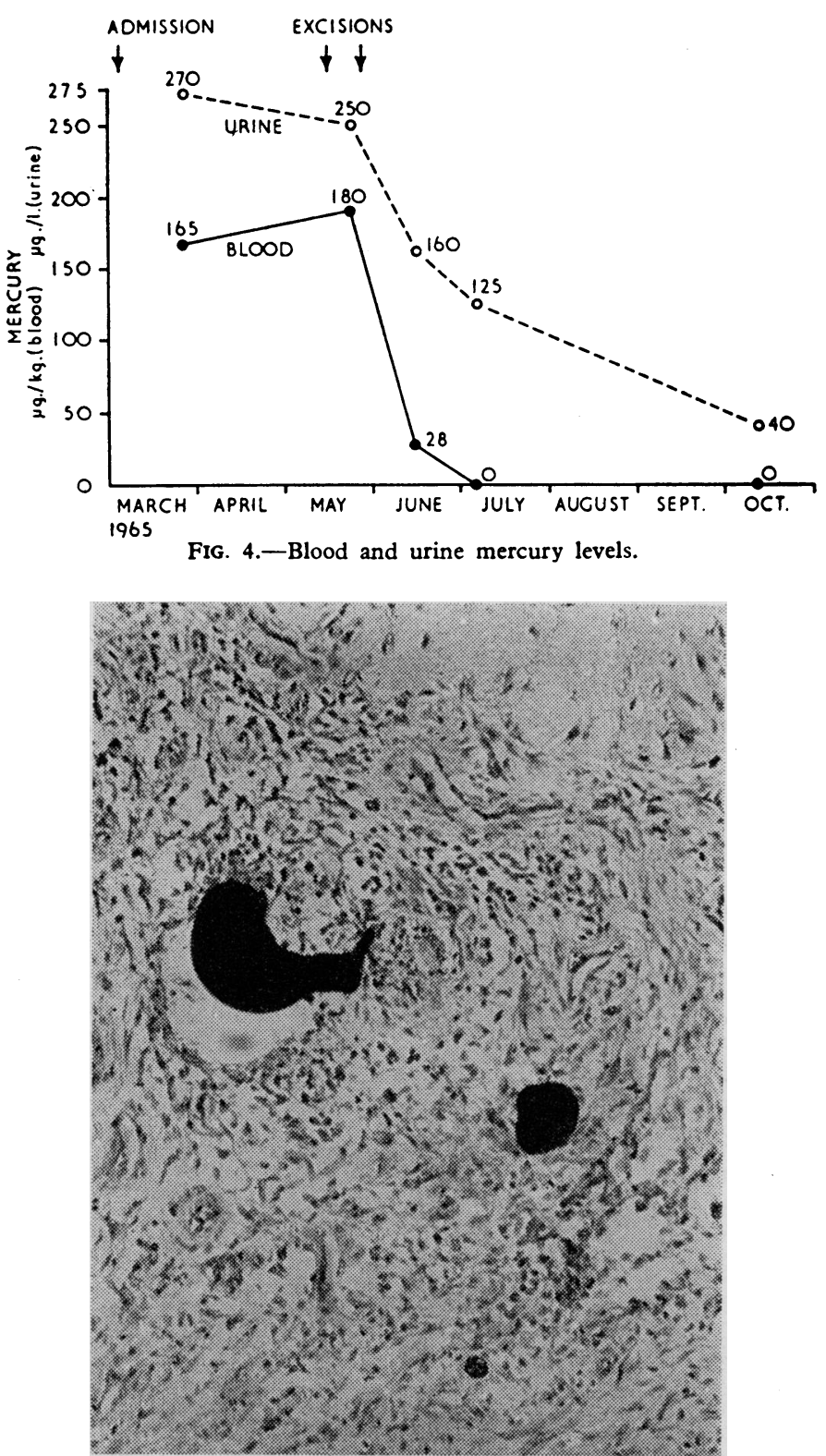

FIg 5-Histological section of subcutaneous tissue showing cellular reaction to mercury particles.
Sollmann, 1957), and there are few firm data in the literature. Leschke (1934) quoted the celebrated case earlier reported by Umber (1923) of a doctor's daughter who in 1922 injected $2 \mathrm{ml}$. of metallic mercury intravenously into herself in a suicidal attempt; within three days she developed severe abdominal pain, stomatitis, and proteinuria, with mercurial embolization of the pulmonary circulation on $x$-ray examination, but five months later had lost all manifestations, including the proteinuria, and lived a further 10 years, to die of an intercurrent infection. Conrad et al. (1957) reported a similar incident, dose unknown, with survival after a week's acute systemic illness. More recently there have been several reports (Lathem et al., 1954 ; Schultz and Beskind, 1960 ; Buxton et al., 1965 ; Lancet, 1965) of mercury embolization after use of the metal as an aerobic seal and mixer in blood-gas sampling syringes.

In the present case the dose administered-presumably from the patient's or the dentist's supply of syringes and needles through all common sizes of which mercury flows with easeis uncertain. $U p$ to the time of writing the patient denies self-administration, offering no alternative explanation. However, from study of the initial $x$-ray films and observation of the quantities removed from each abscess, it is probable that between 1 and $2 \mathrm{ml}$. of mercury was originally present in the right thigh and 0.5 to $1 \mathrm{ml}$. in the left, giving an estimated initial dose of between 20 and $40 \mathrm{~g}$.; of this, $3.5 \mathrm{~g}$. still remained in situ 12 weeks later, when the block excisions were performed.

Mercury has been estimated in the urine for several decades, but in the blood only more recently (Benning, 1958). Normally it is undetectable in the latter, and present in the former at a concentration of less than $80 \mu \mathrm{g} . / 1$. In chronic mercurial poisoning urine levels usually exceed $300 \mu \mathrm{g}$./l. (Lane, 1954), and may rise towards 3,000 $\mu \mathrm{g} . / 1$. (Goldwater et al., 1962), with blood levels in one survey (Goldwater et al., 1962) between 0 and $496 \mu \mathrm{g} . / \mathrm{kg}$. blood, the correlation between the two being poor. No previous information on such levels in acute intoxication appears to exist.

\section{Summary}

The case is reported of a 21-year-old diabetic woman who injected between 20 and $40 \mathrm{~g}$. of metallic mercury subcutaneously into her thighs. Maximum mercury levels of $180 \mu \mathrm{g} . / \mathrm{kg}$. blood and of $270 \mu \mathrm{g}$. $/ \mathrm{l}$. urine were observed, both falling to normal after block excisions of the metal under dimercaprol cover had been performed. No clinical features of either acute or chronic mercury poisoning developed.

I wish to thank Dr. W. G. Oakley for permission to report this case ; Professor John Anderson, Mr. A. J. Heriot, and Dr. G. Stewart Prince for their comments on the manuscript; and Dr. G. S. Anderson for Fig. 5. The Laboratory of the Government Chemist kindly undertook the mercury analysis.

\section{REFERENCES}

Analytical Methods Committee (1965). Analyst, 90, 515.

Benning, D. (1958). Industr. Med. Surg., 27, 354.

Bidstrup, P. L. (1964). The Toxicity of Mercury and Its Compounds. Amsterdam.

Buxton, J. T., jun., Hewitt, J. C., Gadsden, R. H., and Bradham, G. B. (1965). f. Amer. med. Ass., 193, 573.

Conrad, M. E., jun., Sanford, J. P., and Preston, J. A. (1957). Arch. intern. Med., 100, 59.

Goldwater, L. J., Jacobs, M. B., and Ladd, A. C. (1962). Arch. environm. Hith, 5, 537 .

Goodman, L. S., and Gillman, A. Z. (1965). Pharmacological Basis of Therapeutics : a Textbook of Pharmacology, 3rd ed. London.

Hunter, D. (1962). The Diseases of Occupations, 3rd ed. London. Lancet, 1965, 2, 1174.

Lane, R. E. (1954). Brit. med. F., 1, 978.

Lathem, W., Lesser, G. T., Messinger, W. J., and Galdston, M. (1954). Arch. intern. Med., 93, 550.

Leschke, E. (1934). Clinical Toxicology. London.

Oakley, W., Hill, D., and Oakley, N. (1966). Diabetes, 15, 219.

Richter, E." (1910). Berl. klin. W schr., 47, 1588.

Schulz, E., and Beskind, H. (1960). \%. Pediat., 57, 733.

Sollmann, T. (1957). A Manual of Pharmacology, 8th ed. Philadelphia. Umber, F. (1923). Med. Klin., 19, 35. 